\title{
Perbandingan Usability Sistem Operasi Antara Windows dan Macintosh di Universitas Negeri Manado
}

\author{
John Reimon Batmetan, Ronaldo Muyu, Christy Poluakan, Undap E.B Yeremia \\ Prodi Pendidikan Teknologi Informasi dan Komunikasi, Universitas Negeri Manado, Tondano. 95318 \\ john.reimon@gmail.com, Ronaldo.muyu@gmail.com, Mpoluakanc73@gmail.com, Rico.undap@gmail.com
}

\begin{abstract}
ABSTRAK
Sistem operasi merupakan perangkat lunak system computer yang paling penting, Saat ini ada beberapa system operasi yang begitu popular diantaranya adalah Windows dan MacOS. Dilakukan pengukuran usability antara system operasi Windows dan MacOS. Penelitian ini bertujuan untuk mengukur perbandingan penggunaan antara system operasi Windows dan Mac dalam perkuliahan di Universitas Negeri Manado. Dalam penelitian ini menggunakan kuesioner dengan 13 pertanyaan yang diajukan dan 25 responden yang diterima, kemudian dilakukan alanisa data menggunakan skala pengukur guttman. Hasil penelitian menunjukan bahwa system operasi windows lebih banyak digunakan dengan presentase yang jauh lebih tinggi dari MacOS. Hasil penelitian ini juga lebih memilih system operasi windows dengan $84.61 \%$ sedangkan MacOS dengan $11.38 \%$. Karena mulai dari segi popularitas dikalangan mahasiswa Universitas Manado, banyak yang menggunakan Windows karna dianggap lebih mudah dan aplikasi yang disediakan secara gratis berbeda dengan MacOS yang prabayar.
\end{abstract}

Kata Kunci : Sistem operasi, Windows, MacOS, Usability, UNIMA

\section{PENDAHULUAN}

Sistem operasi adalah seperangkat program yang mengelola sumber daya perangkat keras komputer, dan menyediakan layanan umum untuk aplikasi perangkat lunak. Sistem operasi adalah jenis yang paling penting dari perangkat lunak sistem dalam sistem komputer. Tanpa sistem operasi, pengguna tidak dapat menjalankan program aplikasi pada komputer mereka, kecuali program aplikasi booting. Sistem operasi mempunyai penjadwalan yang sistematis mencakup perhitungan penggunaan memori, pemrosesan data, penyimpanan data, dan sumber daya lainnya[1]. Contoh sistem operasi modern adalah Linux, Android, iOS, Mac OS X, dan Microsoft Windows.[2]

Menurut Dony Ariyus (2010:137) "Windows adalah salah satu software sistem operasi yang dikeluarkan oleh perusahaan Microsoft Inc. Microsoft Windows adalah software sistem informasi yang paling populer untuk para pengguna PC. Tampilan Windows yang "user friendly" membuatnya menjadi pilihan utama"[3]. Macintosh adalah nama dari komputer yang di buat oleh Apple inc. tidak seperti windows yang dijual bebas dan dapat diinstalasikan ke hampir semua merek komputer, Mac OS hanya dapat diinstalasikan secara legal ke komputer Apple Macintosh. Setiap pembelian baru sebuah komputer Apple secara otomatis akan mendapatkan Mac OS beserta beberapa aplikasi bawaan (iLife Suite, Comic Life)[4]. Keamanan sistem operasi merupakan bagian masalah keamanan sistem komputer secara total. Keamanan sistem komputer adalah untuk menjamin sumber daya tidak digunakan atau dimodifikasi oleh orang yang tidak diotorisasi[2].

Usability berasal dari kata usable yang secara umum berarti dapat digunakan dengan baik. Sesuatu dapat dikatakan berguna dengan baik apabila kegagalan dalam penggunaannya dapat dihilangkan atau diminimalkan serta memberi manfaat dan kepuasan kepada pengguna[5]. Untuk mengukur Usability bergantung pada kemampuan penggunan menyelesaikan serangkaian tes. Beberapa parameter untuk mengukur Usability meliputi :

1) Success Rate, mengukur tingkat keberhasilan pengguna dalam menyelesaikan semua "tugas" yang ada pada suatu website. 
2) The Time a Task Requires, mengukur waktu yang dibutuhkan oleh seorang pengguna dalam menyelesaikan suatu "tugas" pada website tersebut.

3) Error Rate, tingkat kesalahan yang dilakukan oleh pengguna pada saat menyelesaikan "tugas" pada website tersebut.

4) User's Subjective Satisfaction, tingkat kepuasan pengguna dalam menyelesaikan keseluruhan "tugas" ketika berinteraksi dalam website tersebut.[5]

Penelitian ini bertujuan untuk mengukur perbandingan penggunaan antara system operasi Windows dan Mac dalam perkuliahan di Universitas Negeri Manado. Salah satu paket kuisioner yang dapat digunakan untuk mengukur usability adalah USE. USE dapat mencakup 3 aspek pengukuran usability menurut ISO yaitu efisiensi, efektivitas dan kepuasan. Beberapa penelitian yang sudah dilakukan menunjukkan bahwa kebanyakan evaluasi produk mengacu pada tiga dimensi tersebut, yaitu usefulness, satisfaction dan ease of use[6].

\section{METODE PENELITIAN}

\section{Metode Pengumpulan Data}

Metode pengumpulan data merupakan aspek penting dalam penelitian ini karena perannya dalam kelancaran dan keberhasilan dalam suatu penelitian. Dalam penelitian ini metode pengumpulan data dilakukan dengan metode penyebaran angket atau kuisioner melalui media survei untuk mendapatkan data. Bentuk pertanyaan adalah pilihan ganda (multiple choice questions). Kuisioner terbuka (opened questionare) Merupakan kuisioner yang pertanyaan atau pernyataannya memberikan kebebasan kepada responden untuk memberikan jawaban dan pendapatnya sesuai dengan keinginan mereka[5]. Pada kuisioner disini data dihitung menggunakan Skala Guttman. Skala Guttman merupakan skala yang digunakan untuk memperoleh jawaban dari responden yang bersifat jelas (tegas) dan konsisten. Pada skala ini hanya mempunyai dua skor, yaitu skor 1 untuk pertanyaan atau pernyataan yang mendukung dan skor 0 untuk pertanyaan atau pernyataan yang tidak mendukung [7].

Pengumpulan data dalam penelitian ini, yaitu untuk melihat usability perbandingan antara sistem operasi Windows dan MacOS bagi para Mahasiswa UNIMA yang dilakukan dengan cara sebagai berikut:
1) Membuat kuisioner untuk dibagikan kepada para Mahasiswa.

2) Mengambil sampel data dari para Mahasiswa lewat kuisioner yang dibagikan.

3) Mengukur usability (kebergunaan) berdasarkan data dari para Mahasiswa mengenai kedua sistem operasi tersebut sehingga mendapatkan perbandingan.

\section{Analisis Data}

Setelah data berupa kuisioner terisi dan terkumpul, maka akan dilakukan tahapan pengolahan data sebagai berikut:

1) Dilakukan pemeriksaan data (kuisioner) untuk menentukan berapa jumlah data yang terkumpul.

2) Setelah data didapatkan maka kita akan mulai menghitung presentase pengukuran lewat jawaban yang diberikan para responden.

3) Untuk menghitung persentase jawaban responden kita menggunakan pengukuran skala Guttman dengan cara : Jumlah Ratarata / Jumlah Responden x 100\%

4) Hasil dari proses pengolahan data diatas akan menentukan presentase tingkat kebergunaan (usability) dari kedua sistem operasi tersebut pada kalangan Mahasiswa UNIMA.

\section{HASIL PENELITIAN}

Dalam penelitian ini, peneliti menggunakan media google form sebagai media kuesioner kepada mahasiswa di Universitas Manado berisi 13 pertanyaan. Kuesioner yang suda dibagikan kemudian diisi oleh pengguna berdasarkan pengalaman saat menggunakan system operasi Windows dan MAC.

Dalam menganalisa data, peneliti menggunakan pengukur skala Guttman.

$$
\frac{\text { Jumlah Rata-rata }}{\text { Jumlah Responden }} \times 100 \%
$$

Tabel 1. Presentasi Pengukuran

\begin{tabular}{ccc}
\hline Pertanyaan & $\begin{array}{c}\text { Jawaban } 1 \\
= \\
\text { Windows }\end{array}$ & $\begin{array}{c}\text { Jawaban } \\
0= \\
\text { MacOS }\end{array}$ \\
\hline P1 & 24 & 1 \\
\hline P2 & 18 & 7 \\
\hline P3 & 23 & 2 \\
\hline
\end{tabular}




\begin{tabular}{ccc}
\hline P4 & 23 & 2 \\
\hline P5 & 23 & 2 \\
\hline P6 & 24 & 1 \\
\hline P7 & 23 & 2 \\
\hline P8 & 19 & 6 \\
\hline P9 & 22 & 3 \\
\hline P10 & 23 & 2 \\
\hline P11 & 23 & 2 \\
\hline P12 & 21 & 4 \\
\hline P13 & 22 & 3 \\
\hline Jumlah/Total & 288 & 37 \\
\hline Rata-Rata & 22.15 & 2.84 \\
\hline
\end{tabular}

Menghitung Presentase Rumus:

$$
\frac{\text { Jumlah Rata-rata }}{\text { Jumlah Responden }} \text { X 100\% }
$$

Presentase Windows:

$$
\frac{22.15}{25} \times 100 \%=88.61 \%
$$

Presentase MacOS :

$$
\frac{2.84}{25} \times 100 \%=11.38 \%
$$

Jadi dari hasil pengukuran ini, didapatkan para responden lebih memilih sistem operasi windows dengan $88.61 \%$ daipada menggunakan MacOS dengan $11.38 \%$.

\section{KESIMPULAN}

Dari data yang terkumpul diatas, dilakukan perhitungan dimana responden lebih memilih system operasi windows dengan $84.61 \%$ sedangkan MacOS dengan $11.38 \%$. Karena mulai dari segi popularitas dikalangan mahasiswa Universitas Manado, banyak yang menggunakan Windows karna dianggap lebih mudah dan aplikasi yang disediakan secara gratis berbeda dengan MacOS yang prabayar. Namun ada sebagian yang memilih MacOS karna dinilai memiliki interface yang elegan dan system keamanan yang kuat. Dalam penggunaan system operasi, baiklah kita memperhatikan kebutuhan yang menjadi hal utama bagi para user serta kemudahan menggunakannya, tak lupa juga memperhatikan kemanan data dari user. Di jaman modern saat ini kebanyakan pengguna lebih mementingkan kemudahan dari pada keamanan.

\section{REFERENSI}

[1] M. Fanny, "ANALISIS UJI KOMPARASI SISTEM OPERASI PADA."

[2] “Tegar2017,PerbandinganBLdanLazada.pdf. $"$.

[3] P. Bidang, K. Sains, and D. Silvia, "Jurnal Edik Informatika Rancang Bangun Aplikasi Pembelajaran Sistem Operasi Windows Pada Matakuliah Sistem Operasi Di STMIK Indonesia Padang Berbasis Multimedia Interaktif Jurnal Edik Informatika."

[4] U. Beliung and B. Bri, "Indonesia Journal of Communication," vol. 9, 2012.

[5] W. Handiwidjojo and L. Ernawati, "Pengukuran Tingkat Ketergunaan (Usability ) Sistem Informasi Keuangan Studi Kasus: Duta Wacana Internal Transaction ( Duwit )," vol. 2, no. 1, 2016.

[6] K. Aelani, "PENGUKURAN USABILITY SISTEM MENGGUNAKAN USE QUESTIONNAIRE," vol. 2012, no. Snati, pp. 15-16, 2012.

[7] F. P. Suprobo, D. Suteja, and A. S. D. S, "Desain Sistem Informasi Aplikasi Kuisioner Dengan Skala Guttman Atas Pengembangan Model Audit Pertanggungjawaban Sosial Berbasis Human- Centered Design Laba -," no. November, pp. 265-270, 2013.

[8] J. R. Batmetan Suyoto, J. D. C. L. Suares, "An Empirical Investigation on Customer Behavior to Adopt Mobile Commerce among the $Y$ Generation in Indonesia", Sriwijaya International Conference On Engineering, Science \& Technology [SICEST 2016], 2016

[9] J.R. Batmetan, "Algoritma Ant Colony Optimization (ACO) untuk Pemilihan Jalur Tercepat Evakuasi Bencana Gunung Lokon Sulawesi Utara", Jurnal Teknologi InformasiAITI, 2016, vol.13, no.2, pp 31-48 
[10] L. Madeso, D. R. Kabo, J. R. Batmetan, " Rancang Bangun Sistem Pakar Penentuan Status Gizi Pada Balita Menggunakan Metode Forward Chainning", E-Jurnal UNSRIT, vol.2

[11] J. R. Batmetan, V. R. Palilingan, " Higher Education Students' Behaviour to Adopt Mobile Learning", IOP Conference Series: Materials Science and Engineering, 2018, vol. 306, Issue 1, pp. 012110 (2018)

[12] V. R. Palilingan, J. R. Batmetan, " Incident Management in Academic Information System using ITIL Framework", IOP Conference Series: Materials Science and Engineering, 2018, vol. 306, Issue 1, pp. 012110 (2018)
[13] J. R. Batmetan, A. J. Santoso, Pranowo, " A Multiple-Objective Ant Colony Algorithm for Optimizing Disaster Relief Logistics", Advanced Science Letters, 2017, vol.23, no.3, pp. 2344-2347

[14] M. L. Tompodung, F. Supit, J. R. Batmetan, " Rancang Bangun Aplikasi Sensus Penduduk Berbasis Android", Buletin Sariputra, 2017, vol.7, pp. 57-61

[15] J. R. Batmetan, " Optimasi Strategi Smart Environment Dalam Mitigasi Bencana Menggunakan Multi-Objective Aco (Mo-Aco) Algorithm", Pasca Sarjana Magister Teknik Informatika Universitas Atma Jaya Yogyakarta, 2016 